\title{
E2FI activation is responsible for pituitary adenomas induced by HMGA2 gene overexpression
}

\author{
Monica Fedele ${ }^{1}$, Giovanna Maria Pierantoni ${ }^{1}$, Rosa Visone ${ }^{1}$ and \\ Alfredo Fusco*1,2
}

Address: ${ }^{1}$ Istituto di Endocrinologia e Oncologia Sperimentale del CNR e Dipartimento di Biologia e Patologia Cellulare e Molecolare, Università di Napoli "Federico II", via S. Pansini, 580131 Napoli, Italy and 2NOGEC (Naples Oncogenomic Center) - CEINGE Biotecnologie Avanzate \& SEMM - European School of Molecular Medicine - Naples Site, via Comunale Margherita 482, Naples, Italy

Email: Monica Fedele - mfedele@unina.it; Giovanna Maria Pierantoni - gmpieran@unina.it; Rosa Visone - rosavisone@hotmail.com; Alfredo Fusco* - afusco@napoli.com

* Corresponding author

Published: 17 August 2006

Cell Division 2006, I:17 doi:10.1186/1747-1028-1-17

This article is available from: http://www.celldiv.com/content/I/I/I7

(c) 2006 Fedele et al; licensee BioMed Central Ltd.

This is an Open Access article distributed under the terms of the Creative Commons Attribution License (http://creativecommons.org/licenses/by/2.0), which permits unrestricted use, distribution, and reproduction in any medium, provided the original work is properly cited.
Received: 20 July 2006

Accepted: 17 August 2006

\begin{abstract}
The High Mobility Group protein HMGA2 is a nuclear architectural factor that plays a critical role in a wide range of biological processes including regulation of gene expression, embryogenesis and neoplastic transformation. Several studies are trying to identify the mechanisms by which HMGA2 protein is involved in each of these activities, and only recently some new significant insights are emerging from the study of transgenic and knock-out mice. Overexpression of HMGA2 gene leads to the onset of prolactin and $\mathrm{GH}$-hormone induced pituitary adenomas in mice, suggesting a critical role of this protein in pituitary tumorigenesis. This was also confirmed in the human pathology by the finding that HMGA2 amplification and/or overexpression is present in human prolactinomas. This review focuses on recent data that explain the mechanism by which HMGA2 induces the development of pituitary adenomas in mice. This mechanism entails the activation of the E2FI protein by the HMGA2-mediated displacement of HDACI from PRB protein.
\end{abstract}

\section{Background}

Pituitary tumors constitute $10 \%$ of intracranial neoplasms, and are mostly benign with slow growth [1]. Most pituitary neoplasms secrete hormone gene products, leading to disturbed endocrine functions. Prolactinomas account for the most common type of pituitary adenomas $[1,2]$, while about one-third of pituitary adenomas are not associated with clinical hypersecretory syndromes, but with symptoms of an intracranial mass that leads to headaches, hypopituitarism or visual-field disturbances, which are classified as non-functioning pituitary adenomas (NFPAs). The genesis of pituitary tumors is still mainly unknown, but the actual model supposes that genetic alterations represent the initializing event that transforms pituitary cells, and that hypothalamic hormones and other local growth factors may play an important role in promoting the growth of already transformed cells. However, the classical gene alterations involved in cell transformation, such as ras, BRAF, $R b$, do not appear to be responsible for the onset of pituitary adenomas [3]. Only up to $40 \%$ of sporadic human GH-secreting adenomas have missense mutations of the Gs $\alpha$ gene [4], and many functional adenomas present the overexpression of a recently discovered powerful transforming gene, PTTG, which is able to exert strong transforming effects both in vitro and in vivo [5]. 
Recently, our group suggested a critical role for highmobility group A2 (HMGA2) gene in pituitary oncogenesis. In fact, transgenic mice expressing high levels of the HMGA2 gene develop pituitary adenomas secreting prolactin and growth hormone [6], (Figure 1).

The HMGA2 protein belongs to the HMGA family. The HMGA protein family members are non-histones, small, nuclear proteins, that bind the minor groove of AT-rich DNA sequences through their "AT-hook" domains localised in the N-terminal region of the proteins [7]. These proteins play key roles in chromatine architecture and gene control by serving as generalized chromatin effectors, either enhancing or suppressing the ability of more usual transcriptional factors to act in transcriptional regulation [8].

HMGA2 expression is restricted during embryogenesis, whereas it is absent or very low in normal adult tissues $[9,10]$. Induction of HMGA2 gene expression occurs in several human malignant neoplasias, including thyroid $[11,12]$, pancreas [13], breast [14], and colorectum [1517], and seems to play a critical role in cell transformation, since the block of its synthesis prevents rat thyroid transformation by murine transforming retroviruses [18]. Conversely, rearrangements of the HMGA2 gene are frequently detected in human benign tumors of mesenchymal origin [19]. Consistent with the onset of pituitary adenomas in HMGA2-transgenic mice, we have found the induction of HMGA2 expression in human prolactinomas in association with amplification and/or rearrangement of the gene [20], and, recently, we have shown that also the majority of NFPAs express HMGA2, but, in these cases, it is not associated to over-representation of the HMGA2 region [21].

\section{HMGA2 binds to pRB and inhibits its function}

The Retinoblastoma protein, $\mathrm{pRB}$, has been suggested to be a key protein in the pituitary tumorigenesis because of the pituitary tumors developed by $R B+/-$ mice [22], but no RB mutations, apart from few high aggressive pituitary carcinomas [23], have been so far reported in human pituitary pathology [24]. However, methylation of the $R B$ gene-promoter region at a CpG island, resulting in loss of protein expression, has been described in human pituitary tumor cells [25], suggesting that pRB is indeed critical in human pituitary tumorigenesis.

pRB controls cell cycle progression through its interaction with the E2F family of transcription factors [26,27], whose activity is crucial for the expression of several genes required to enter the $S$ phase of the cell cycle $[28,29]$. The transcriptional activity of E2F1 is repressed in non-proliferating cells by its interaction with $\mathrm{pRB}$ that masks the activation domain of E2F1, and prevents it to contact the

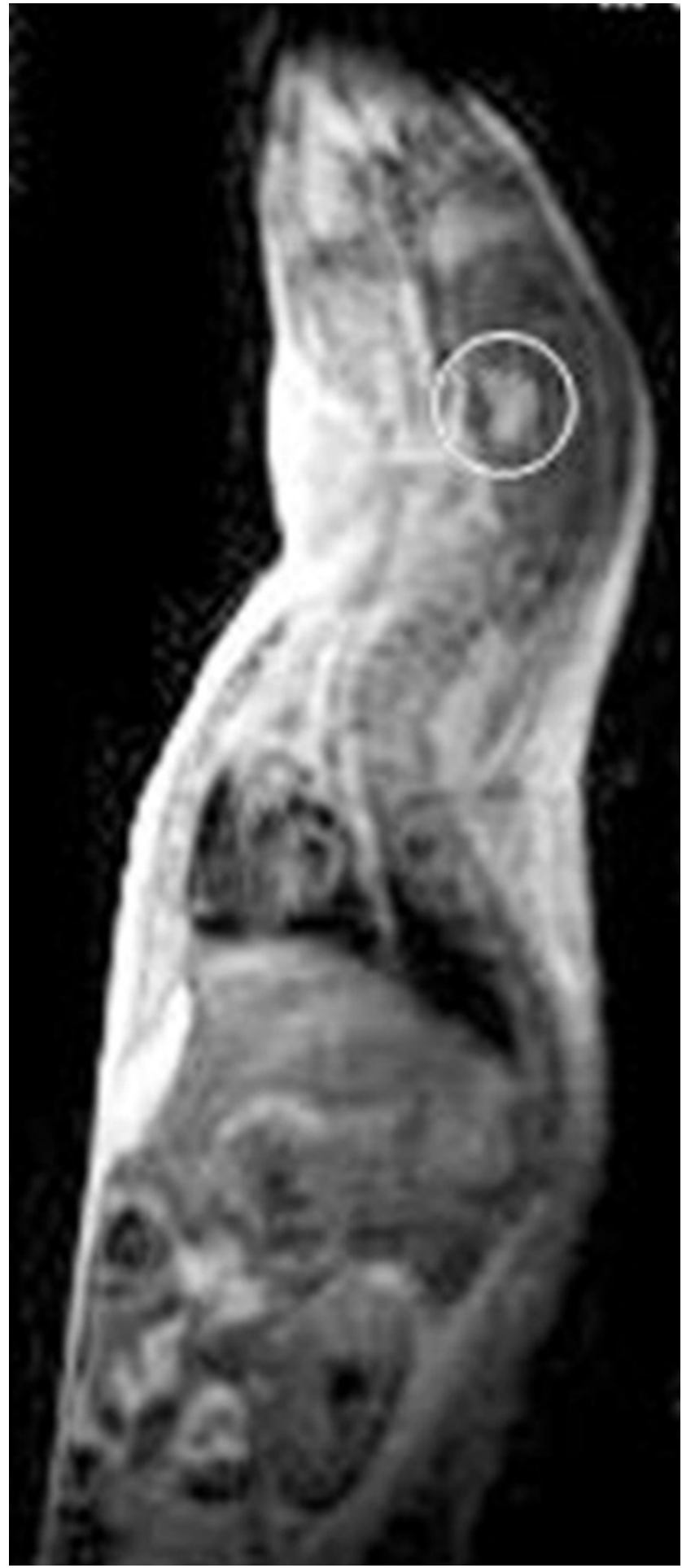

Figure I

Magnetic Resonance Image of a HMGA2 transgenic mouse showing a pituitary adenoma (indicated in circle).

general transcription machinery [30]. Conversely, in proliferating cells, pRB is phosphorylated at multiple sites by 
cyclin-dependent kinases [31,32], resulting in the release of E2F1 and, consequently, transcriptional activation of its target genes [33]. More recently, a new mechanism of pRB-mediated E2F1 repression has been suggested in addition to this one. It is an active repression that $\mathrm{pRB}$ exerts on E2F1-mediated transcription by recruiting class I histone deacetylase proteins (HDAC1) to the E2F1-sites. The HDACs repress transcription by removing acetyl groups from the histones, thereby facilitating the condensation of nucleosomes into chromatin and therefore blocking access to transcription factors [34].

Based on the striking mirror similarities between the phenotypes of pRB [22,35] and HMGA2 [36,37] animal models, our group has recently investigated a potential functional interaction between HMGA2 and the Retinoblastoma protein [38]. By co-immunoprecipitating HMGA2 and pRB in pituitary adenomas developed by HMGA2 mice, we demonstrated the interaction between the two proteins occurring in the tumor. This interaction was then repeated and confirmed in vitro with recombinant proteins, finding that one of the pRB domains involved in the interaction is the A/B pocket [30], the same domain that is also involved in the interaction with E2F1, HDAC1 and viral oncoproteins such as those produced by the E1A adenovirus $[39,40]$. This was very interesting because it suggested that HMGA2, similarly to the viral oncoproteins, could inhibit $\mathrm{pRB}$ function by displacing E2F1 and HDAC1 from pRB. By transfection, luciferase and colony assays, we could establish that the overexpression of HMGA2 antagonizes the activity of $\mathrm{pRB}$. In fact it blocks the pRB-dependent inhibition of both E2F1 target gene transcription and cell proliferation. Interestingly, this positive role of HMGA2 on cell prolifer- ation is due to the interaction with $\mathrm{pRB}$, opening a new class of cell cycle related proteins: "the suppressors of the cell cycle inhibitors". As described above, HMGA2 is considered a bona fide oncogene because it induces both neoplastic transformation of cultured rat fibroblasts [41] and tumors in transgenic mice [6]. Interestingly, we found that the interaction between HMGA2 and pRB is crucial for the transforming activity of HMGA2 protein. In fact, in a focus assay on rat fibroblasts, HMGA2 mutants unable to bind $\mathrm{pRB}$ lost the capacity of the wild-type gene to transform cells. These results suggest that the binding between HMGA2 and pRB may be generally involved in HMGA2mediated cell transformation.

\section{HMGA2 displaces HDACI from E2FI target promoters and causes acetylation of both histones and E2FI protein}

Using competitions with recombinant proteins and Chromatin Immonoprecipitation (ChIP) experiments, we demonstrated that following the binding of HMGA2 to pRB (Figure 2, step1), HDAC1 is displaced from the E2F1target promoters (Figure 2, step 2) where it was recruited by pRB [34]. Consistently, HDAC1 activity associated to pRB is lower in cells and pituitary adenomas overexpressing HMGA2 than in mock-transfected cells and normal pituitary, respectively [38]. Histone acetyl transferases and histone deacetylases acetylate and deacetylate core histone tails that protrude from the nucleosome. Histone acetylation is thought to weaken the interaction between histone N-terminal tails and DNA, thus opening up the chromatin and increasing accessibility for activating transcription factors $[42,43]$. Therefore, the displacement of HDAC1 from pRB results in the recruitment of histone acetyl transferase to the E2F1-target promoters and

Step1: Binding of HMGA2Step2: Displacement of HDAC1Step3: Acetylation of histonesStep4: Acetylation of E2F1
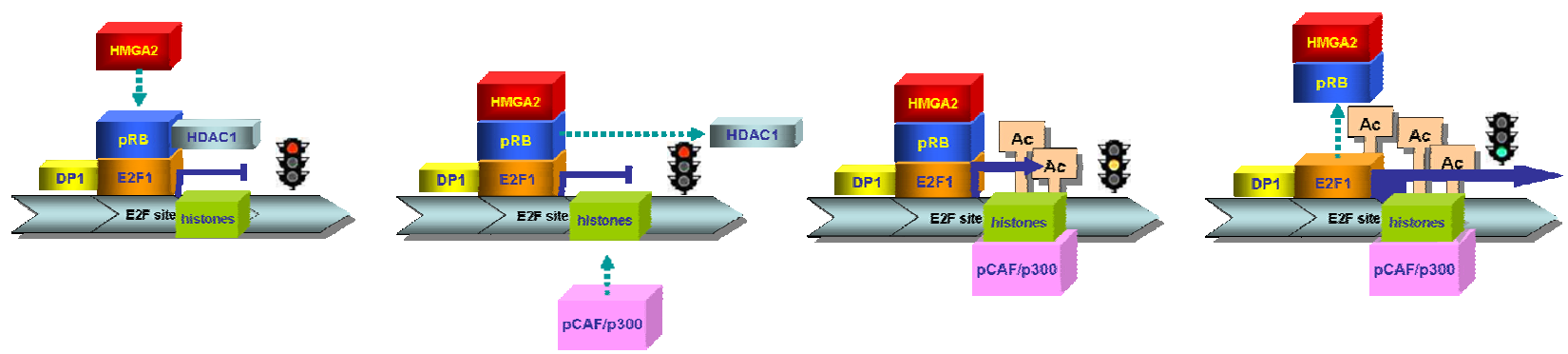

Figure 2

Schematic model of E2FI activation by HMGA2. Following HMGA2 overexpression, transcription through E2FI sites switches from repression to activation through four steps: I- HMGA2 binds to PRB, which is complexed with E2FI and HDACI to form the active repression; 2- the interaction between HMGA2 and PRB displaces HDACI; 3- in the absence of $\mathrm{HDACl}$, the histone acetylase enzymes are recruited and, by acetylating histones, relieve transcriptional repression; 4- histone acetylases also acetylate E2FI causing the stabilization of its "free" active form. 
acetylation of both histones and other proteins, including E2F1. This was convincingly demonstrated by ChIP experiments using antibodies against acetylated histone $\mathrm{H} 3$ and E2F1 [38]. The acetylation of both histones and E2F1 protein increase about two-fold the E2F1 transcriptional activity. In fact, as above described, the acetylation of histones opens up the chromatin and facilitates gene transcription (Figure 2, Step 3). Moreover, acetylation of E2F1 augments its DNA binding and stabilizes the protein in its "free" active form [44] (Figure 2, Step 4). Thus, as a consequence of the E2F1 acetylation, HMGA2 can indirectly also cause the displacement of E2F1 from pRB as it was observed by ChIP and re-ChIP experiments on the cyclin E1 promoter [38].

\section{Suppression of pituitary tumorigenesis in HMGA2 transgenic mice lacking E2F I}

Does the afore-reported HMGA2-dependent molecular events result in enhanced E2F1-dependent gene transcription in pituitary adenomas? The affirmative answer comes once again from the study of the HMGA2 transgenic mice. In fact, pituitary adenomas excised from these mice were used in EMSA assays to analyze the E2F1-DNA binding in pituitary tumours compared to normal pituitary glands from wild-type mice [38]. The data obtained showed a drastic increase of the "free" active form of the E2F/DNA complex. Moreover, by RT-PCR and ChIPs on tissues, expression of E2F-target genes, such as CDC1 and TK1, was shown to be enhanced, and E2F1 to be more acetylated in adenomas compared to normal glands (unpublished data). This suggests that E2F1 activity is a critical event in pituitary tumorigenesis of HMGA2 mice.

To address this hypothesis, we crossed HMGA2 transgenic mice with E2F1 knock-out mice to generate double mutants [38]. With our big satisfaction, the hypophysis of these mice was only rarely and however minimally interested to the adenomatous phenotype. In fact, the adenoma was diagnosed in only $25 \%$ of double mutant mice in respect to HMGA2 transgenic mice which all developed pituitary tumors. Moreover the tumours of the mice lacking E2F1 were smaller and slower growing than those developed by the HMGA2 mice. Interestingly, even in pituitary adenomas developed by HMGA2 mice lacking E2F1 the interaction between HMGA2 and pRB was present, however, the E2F "free" DNA binding activity did not show any significant increase compared to control wild-type glands. Conversely, an increase in E2F "free" DNA binding was always observed in pituitaries from single mutant HMGA2 mice even before the appearance of the pituitary tumour. Thus, even though HMGA2 is still able to bind $\mathrm{pRB}$ in the absence of E2F1, there are no other proteins belonging to the E2F family, whose DNA binding activity is enhanced following the HMGA2/pRB interaction. Therefore, it is likely that other E2F-independ- ent mechanisms are responsible for the pituitary alterations observed in the minority of these mice.

\section{Conclusion}

Our data demonstrate that E2F1 activation is a crucial step required for the onset of pituitary adenomas in HMGA2 transgenic mice. Since HMGA2 amplification and overexpression has been detected also in human pituitary adenomas, we retain that E2F1 activation plays a critical role also in the human pituitary pathology.

These conclusions are not completely unexpected since several studies have previously demonstrated that alterations of the pRB/E2F pathway are critical for the development of pituitary adenomas in mice [45-47]. However, what appears to be really novel, is the mechanism that leads to E2F1 activation by HMGA2: the E2F1 protein is not displaced from the pRB complex, but an increased acetylation that is dependent on the removal of HDAC1 from $\mathrm{pRB}$ takes place. It would be very interesting to know whether the same mechanism may be induced by other proteins able to bind to the $\mathrm{PRB}$ complex and thereby are involved in pituitary tumorigenesis. To answer to this question, it would be interesting to evaluate the acetylation status of the E2F1 protein in pituitary adenomas when the HMGA2 is overexpressed or not. The presence of E2F1 hyperacetylation in the absence of HMGA2 overexpression would suggest the involvement of other proteins acting with the same or similar mechanism of HMGA2 protein, or alternatively other mechanisms that eventually lead to an increase in E2F1 acetylation and subsequent activation.

\section{Acknowledgements}

This work was supported by grants from the Associazione Italiana Ricerca sul Cancro (AIRC). We are very grateful to Dr. Carlo M. Croce for his continuous and friendly support to our research group.

\section{References}

I. Kovacs K, Horvath E: Tumors of the pituitary gland. In Atlas of Tumor Pathology. Fascicle 2I, II series Washington, DC: AFPI; 1986.

2. Herman V, Fagin J, Gonsky R, Kovacs K, Melmed S: Clonal origin of pituitary adenomas. J Clin Endocrinol Metab 1990, 7 I:1427-33.

3. Asa SL, Ezzat S: The cytogenesis and pathogenesis of pituitary adenomas. Endocr Rev 1998, 19:798-827.

4. Gilman AG: G-proteins: transducers of receptors-generated signals. Annu Rev Biochem 1987, 56:6 I3-49.

5. Heaney AP, Horwitz GA, Wang Z, Singson R, Meemed S: Early involvement of estrogen-induced pituitary tumor transforming gene and fibroblast growth factor expression in prolactinoma pathogenesis. Nat Med 1999, 5: I 317-20.

6. Fedele M, Battista S, Kenyon L, Baldassarre G, Fidanza V, Klein-Szanto AJ, Parlow AF, Visone R, Pierantoni GM, Outwater E, Santoro M, Croce CM, Fusco A: Overexpression of the HMGA2 gene in transgenic mice leads to the onset of pituitary adenomas. Oncogene 2002, 2 I:3190-8.

7. Reeves R, Nissen MS: The A-T-DNA-binding domain of mammalian high mobility group I chromosomal proteins. A novel peptide motif for recognizing DNA structure. J Biol Chem 1990, 265:8573-82. 
8. Thanos D, Maniatis T: Virus induction of human IFN beta gene expression requires the assembly of an enhanceosome. Cell 1995, 83:1091-100.

9. Zhou X, Benson KF, Ashar HR, Chada K: Mutation responsible for the mouse pygmy phenotype in the developmentally regulated factor HMGI-C. Nature 1995, 376:77I-4.

10. Chiappetta G, Avantaggiato V, Visconti R, Fedele M, Battista S, Trapasso F, Merciai BM, Fidanza V, Giancotti V, Santoro M, Simeone A, Fusco A: High level expression of the HMGAI gene during embryonic development. Oncogene 1996, 13:2439-46.

II. Chiappetta G, Bandiera A, Berlingieri MT, Visconti R, Manfioletti G, Battista S, Martinez-Tello FJ, Santoro M, Giancotti V, Fusco A: The expression of the high mobility group HMGAI proteins correlates with the malignant phenotype of human thyroid neoplasms. Oncogene 1995, 10:1307-14.

12. Chiappetta G, Tallini G, De Biasio MC, Manfioletti G, Martinez-Tello FJ, Pentimalli F, de Nigris F, Mastro A, Botti G, Fedele M, Berger N, Santoro M, Giancotti V, Fusco A: Detection of high mobility group I $\mathrm{HMGI}(Y)$ protein in the diagnosis of thyroid tumors: HMGI(Y) expression represents a potential diagnostic indicator of carcinoma. Cancer Res 1998, 58:4193-8.

13. Abe N, Watanabe T, Izumisato Y, Masaki T, Mori T, Sugiyama M, Chiappetta G, Fusco A, Fujioka $Y$, Atomi Y: Diagnostic significance of high mobility group $I(Y)$ protein expression in intraductal papillary mucinous tumors of the pancreas. Pancreas 2002, 25:198-204.

14. Chiappetta G, Botti G, Monaco M, Pasquinelli R, Pentimalli F, Di Bonito M, D'Aiuto G, Fedele M, luliano R, Palmieri EA, Pierantoni GM, Giancotti $V$, Fusco A: HMGAI protein overexpression in human breast carcinomas: correlation with ErbB2 expression. Clin Cancer Res 2004, 10:7637-44.

15. Fedele M, Bandiera A, Chiappetta G, Battista S, Viglietto G, Manfioletti G, Casamassimi A, Santoro M, Giancotti V, Fusco A: Human colorectal carcinomas express high levels of high mobility group HMGI(Y) proteins. Cancer Res 1996, 56:1896-90I.

16. Abe N, Watanabe T, Sugiyama M, Uchimura H, Chiappetta G, Fusco A, Atomi Y: Determination of high mobility group I(Y) expression level in colorectal neoplasias: a potential diagnostic marker. Cancer Res 1999, 59: I169-74.

17. Chiappetta G, Manfioletti G, Pentimalli F, Abe N, Di Bonito M, Vento MT, Giuliano A, Fedele M, Viglietto G, Santoro M, Watanabe T, Giancotti $\bigvee$, Fusco A: High mobility group HMGI(Y) protein expression in human colorectal hyperplastic and neoplastic diseases. Int J Cancer 200I, 91: I47-5I.

18. Berlingieri MT, Manfioletti G, Santoro M, Bandiera A, Visconti R, Giancotti V, Fusco A: Inhibition of HMGI-C protein synthesis suppresses retrovirally induced neoplastic transformation of rat thyroid cells. Mol Cell Biol 1995, I5:1545-53.

19. Fedele M, Battista S, Manfioletti G, Croce CM, Giancotti V, Fusco A: Role of the high mobility group $A$ proteins in human lipomas. Carcinogenesis 200I, 22:I583-9I. Review

20. Finelli P, Pierantoni GM, Giardino D, Losa M, Rodeschini O, Fedele M, Valtorta E, Mortini P, Croce CM, Larizza L, Fusco A: The high mobility group A2 gene is amplified and overexpressed in human prolactinomas. Cancer Res 2002, 62:2398-405.

21. Pierantoni GM, Finelli P, Valtorta E, Giardino D, Rodeschini $O$, Esposito F, Losa M, Fusco A, Larizza L: High-mobility group A2 gene expression is frequently induced in non-functioning pituitary adenomas (NFPAs), even in the absence of chromosome 12 polysomy. Endocr Relat Cancer 2005, I 2:867-74.

22. Jacks T, Fazeli A, Schmitt EM, Bronson RT, Goodell MA, Weinberg RA: Effects of an Rb mutation in the mouse. Nature 1992, 359:295-300.

23. Pei L, Melmed S, Scheithauer B, Kovacs K, Benedict WF, Prager D: Frequent loss of heterozygosity at the retinoblastoma susceptibility gene (RB) locus in aggressive pituitary tumors: evidence for a chromosome I3 tumor suppressor gene other than RB. Cancer Res 1995, 55:1613-6.

24. Cryns VL, Alexander JM, Kilbanski A, Arnold A: The retinoblastoma gene in human pituitary tumors. J Clin Endocrinol Metab 1993, 77:644-6.

25. Simpson DJ, Hibberts NA, Mc Nicol AM, Clayton RN, Farrell WE: Loss of pRB expression in pituitary adenomas is associated with metylation of the RBI CPG island. Cancer Res 2000, 60:1211-6.
26. Chellappan SP, Hiebert S, Mudryj M, Horowitz JM, Nevins JR: The E2F transcription factor is a cellular target for the RB protein. Cell I99I, 65:1053-61.

27. Helin K, Harlow E, Fattaey A: Inhibition of E2F-I transactivation by direct binding of the retinoblastoma protein. Mol Cell Biol 1993, 1 3:650|-8.

28. Vigo E, Müller H, Prosperini E, Hateboer G, Cartwright P, Moroni $M C$, Helin K: CDC25A phosphatase is a target of E2F and is required for efficient E2F-I induced S phase. Mol Cell Biol I999, 19:6379-95.

29. Muller H, Bracken AP, Vernell R, Moroni MC, Christians F, Grassilli E, Prosperini E, Vigo E, Oliner JD, Helin K: E2Fs regulate the expression of genes involved in differentiation, development, proliferation, and apoptosis. Genes Dev 200I, I 5:267-85.

30. Xiao B, Spencer J, Clements A, Ali-Khan N, Mittnacht S, Broceno C Burghammer M, Perrakis A, Marmorstein R, Gamblin S): Crystal structure of the retinoblastoma tumor suppressor protein bound to E2F and the molecular basis of its regulation. Proc Natl Acad Sci USA 2003, 100:2363-8.

31. Kato J-Y, Matsushime H, Hiebert SW, Ewen ME, Sherr C): Direct binding of cyclin $D$ to the retinoblastoma gene product ( $p R b)$ and $\mathbf{P R b}$ phosphorylation by the cyclin D-dependent kinase CDK4. Genes Dev 1993, 7:331-42.

32. Brown VD, Gallie BL: The B-Domain Lysine Patch of pRB Is Required for Binding to Large T Antigen and Release of E2F by Phosphorylation. Mol Cell Biol 2002, 22:1390-40I.

33. Weinberg RA: The retinoblastoma protein and cell cycle control. Cell 1995, 81:323-30.

34. Magnaghi-Jaulin L, Groisman R, Naguibneva I, Robin P, Lorain S, Le Villain JP, Troalen F, Trouche D, Harel-Bellan A: Retinoblastoma protein represses transcription by recruiting a histone deacetylase. Nature 1998, 391:601-5.

35. Bignon YJ, Chen Y, Chang CY, Riley DJ, Windle JJ, Mellon PL, Lee $\mathrm{WH}$ : Expression of a retinoblastoma transgene results in dwarf mice. Genes Dev 1993, 7:1654-62.

36. Battista S, Fidanza V, Fedele M, Klein-Szanto AJ, Outwater E, Brunner $\mathrm{H}$, Santoro M, Croce CM, Fusco A: The expression of a truncated HMGI-C gene induces gigantism associated with lipomatosis. Cancer Res 1999, 59:4793-7.

37. Fedele M, Battista S, Kenyon L, Baldassarre G, Fidanza V, Klein-Szanto AJ, Parlow AF, Visone R, Pierantoni GM, Outwater E, Santoro M, Croce CM, Fusco A: Overexpression of the HMGA2 gene in transgenic mice leads to the onset of pituitary adenomas. Oncogene 2002, $21: 3190-8$.

38. Fedele M, Visone R, De Martino I, Troncone G, Palmieri D, Battista S, Ciarmiello A, Pallante P, Arra C, Melillo RM, Helin K, Croce CM, Fusco A: HMGA2 induces pituitary tumorigenesis by enhancing E2FI activity. Cancer Cell 2006, 9:459-7I.

39. Hu QJ, Dyson N, Harlow E: The regions of the retinoblastoma protein needed for binding to adenovirus E IA or SV40 large $\mathbf{T}$ antigen are common sites for mutations. $E M B O J$ 1990, 9:1147-55.

40. Morris EJ, Dyson NJ: Retinoblastoma protein partners. Adv Cancer Res 200I, 82: I-54.

41. Wood LJ, Maher JF, Bunton TE, Resar LMS: The oncogenic properties of the HMG-I gene family. Cancer Res 2000, 60:4256-61.

42. Grunstein M: Histone acetylation in chromatin structure and transcription. Nature 1997, 389:349-52.

43. Jenuwein T, Allis CD: Translating the histone code. Science 200 I, 293: 1074-80.

44. Martinez-Balbas MA, Bauer UM, Nielsen SJ, Brehm A, Kouzarides T: Regulation of E2FI activity by acetylation. EMBO J 2000, 19:662-7I.

45. Yamasaki L, Bronson R, Williams BO, Dyson NJ, Harlow E, Jacks T: Loss of E2F-I reduces tumorigenesis and extends the lifespan of Rb I (+/-)mice. Nat Genet 1998, 18:360-4

46. Lee EY, Cam H, Ziebold U, Rayman JB, Lees JA, Dynlacht BD: E2F4 loss suppresses tumorigenesis in Rb mutant mice. Cancer Cell 2002, 2:463-72.

47. Ziebold U, Lee EY, Bronson RT, Lees JA: E2F3 loss has opposing effects on different pRB-deficient tumors, resulting in suppression of pituitary tumors but metastasis of medullary thyroid carcinomas. Mol Cell Biol 2003, 23:6542-52. 